\title{
TINGKAT ADOPSI TANAM JAJAR LEGOWO 2:1 PADA PETANI PADI DI KABUPATEN PURWAKARTA
}

\section{JAJAR LEGOWO 2:1 PLANT ADOPTION LEVEL FOR RICE FARMERS IN PURWAKARTA DISTRICT}

\author{
Bambang Sunandar*, Hepi Hapsari, Lies Sulistyowati \\ Program Studi Ekonomi Pertanian Fakultas Pertanian, Universitas Padjadjaran \\ *E-mail: ibenk1933@gmail.com
}

(Diterima 19-01-2020; Disetujui 23-03-2020)

\begin{abstract}
ABSTRAK
Sistem tanam jajar legowo 2:1 merupakan inovasi pada tanaman padi yang mampu meningkatkan produktivitas tanaman padi melalui peningkatan pupulasi tanaman dengan pengaturan jarak tanam. Penyebarluasan inovasi tersebut telah banyak dilakukan melalui program-program pemerintah, tetapi dalam lima tahun terakhir produktivitas padi di Kabupaten Purwakarta masih rendah dan penerapan inovasi tanam jajar legowo 2:1 masih rendah. Penelitian ini bertujuan untuk mengetahui tingkat adopsi inovasi tanam jajar legowo 2:1 di Kabupaten Purwakarta. Penelitian ini menggunakan desain kuantitatif dengan metode survei. Jumlah responden 130 orang diambil melalui sampel acak berimbang. Data dianalisis dengan menggunakan analisis deskriptif. Hasil penelitian menunjukkan bahwa tingkat adopsi petani terhadap inovasi tanam jajar legowo 2:1 di Kabupaten Purwakarta pada tahap pengetahuan adalah 63,1\% (tinggi), tahap pembujukan 58,8\% (sedang), tahap pengambilan keputusan $85,4 \%$ (sangat tinggi), tahap implementasi $43,8 \%$ (sedang), dan tahap konfirmasi $64,1 \%$ (tinggi).
\end{abstract}

Kata kunci: Tingkat Adopsi, Petani Padi, Tanam Jajar Legowo 2:1

\section{ABSTRACT}

Jajar legowo 2:1 planting system is an innovation in rice plants that can increase rice crop productivity by increasing plant population by adjusting plant spacing. The dissemination of these innovations has been done a lot through government programs, but in the last five years rice productivity in Purwakarta Regency is still low and the application of the innovation of jajar legowo 2:1 planting is still low. This study aims to determine the level of adoption of the jajar legowo 2:1 planting innovation in Purwakarta Regency. This study uses quantitative design with survey methods. The number of respondents was 130 people taken through a propotional random sampling. Data were analyzed using descriptive analysis. The results showed tha the adoption rate of farmers to the innovation of jajar legowo 2:1 in Purwakarta Regency at the knowledge stage was $63.1 \%$ (high), the persuasion stage $58.8 \%$ (moderate), the decision making stage $85.4 \%$ (very high), the implementation phase was $43.8 \%$ (moderate), and the confirmation stage was $64.1 \%$ (high).

Keywords: Adoption rate, rice farmers, jajar legowo 2:1 planting

\section{PENDAHULUAN}

Sistem tanam padi jajar legowo menjadi semakin populer di Jawa Barat pada saat ini, terlebih lagi setelah menjadi salah satu bagian dari komponen teknologi Pengelolaan Tanaman Terpadu (PTT) padi sawah yang wajib diterapkan pada program Sekolah Lapang 
Pengelolaan Tanaman Terpadu (SL-PTT) pada tahun 2011-2014. Dikenal beberapa tipe tanam padi jajar legowo, antara lain: legowo $2: 1, \quad 3: 1, \quad 4: 1$, dan $5: 1$. Berdasarkan beberapa hasil penelitian, tipe tanam jajar legowo yang sesuai dengan kondisi tanah secara umum di Indonesia dan direkomendasikan oleh Badan Litbang Pertanian adalah legowo 2:1 (Sutrisna dan Sunandar, 2012). Jarak tanamnya dapat disesuaikan dengan kondisi lahan dan kesuburan tanah di masing-masing lokasi (spesifik lokasi). Cara tanam padi jajar legowo dalam PTT padi sawah merupakan bagian dari komponen pengaturan populasi tanaman. Dengan demikian, cara tanam padi jajar legowo 2:1 merupakan salah satu cara penanaman padi dengan maksud untuk mengatur populasi tanaman agar jumlahnya optimal. Cara tanam jajar legowo 2:1 dengan berbagai keunggulannya merupakan terobosan teknologi yang paling berpengaruh dalam peningkatan produktivitas padi. Sistem tanam jajar legowo pada prinsipnya adalah meningkatkan populasi dengan cara mengatur jarak tanam. Pengaturan sistem tanam menentukan populasi tanam persatuan luas, kuantitas dan kualitas rumpun tanaman yang pada akhirnya berpengaruh terhadap hasil tanaman.
Tujuannya agar populasi tanaman per satuan luas dapat dipertahankan bahkan dapat ditingkatkan (Suriapermana, dkk., 2000).

Sebagai salah satu inovasi teknologi, tanam Jajar legowo 2:1 telah berkontribusi terhadap peningkatan produksi padi di Jawa Barat. Hasil pengkajian Permadi, et al (2013), penerapan sistem tanam legowo 2:1 menghasilkan produktivitas padi lebih tinggi 1,33 ton/ha dari sistem tanam tegel (biasa). Beberapa hasil penelitian lainnya mengungkapkan bahwa dengan menerapkan teknologi tanam jajar legowo 2:1 mampu menghasilkan produktivitas 7-8 ton/ha.

Beberapa program pemerintah dalam upaya penyebarluasan inovasi tanam jajar legowo 2:1 telah diperkenalkan kepada petani melalui Dinas Pertanian Kabupaten/Kota di Jawa Barat, diantaranya adala : PRIMATANI (Program Rintisan dan Akselerasi Pemasyarakatan Inovasi Teknologi Pertanian) tahun 2006-2009, SL-PTT Padi (Sekolah Lapang Pengelolaan Tanaman dan Sumberdaya Terpadu Padi) tahun 2009-2014, dan GP-PTT (Gerakan Penerapan Pengelolaan Tanaman dan Sumberdaya Terpadu) tahun 2015. Program-program pemerintah tersebut 
diperkenalkan kepada petani melalui demonstrasi plot (demplot) dan dilaksanakan langsung di lahan-lahan petani sehingga diharapkan inovasi tanam jajar legowo 2:1 dapat dirasakan langsung manfaatnya oleh petani.

Salah satu Kabupaten di Jawa Barat yang sudah banyak menerima programprogram pemerintah yang berkaitan dengan inovasi tanam jajar legowo 2:1 adalah Kabupaten Purwakarta. Programprogram pemerintah tersebut diantaranya adalah program PRIMATANI (20072009), program SL-PTT (2009-2014), Demplot pengkajian BPTP Jawa Barat (2012-2013), dan GP-PTT (2015). Dengan adanya program-program tersebut diharapkan inovasi tanam jajar legowo 2:1 dapat diadopsi oleh petani sehingga produktivitas padi di Kabupaten Purwakarta dapat meningkat.

Walaupun program-program pemerintah yang berkaitan dengan penyebarluasan inovasi teknologi tanam jajar legowo 2:1 di Kabupaten Purwakarta sudah berlangsung lama, tetapi kenyataan menunjukan bahwa dalam 5 tahun terakhir produktivitas padi sawah masih rendah dibandingkan dengan Kabupaten lainnya di Jawa Barat. Produktivitas padi di Kabupaten Purwakarta dalam 5 tahun terakhir (BPS
Provinsi Jawa Barat, 2012-2016) rata-rata 5,59 ton/ha termasuk rendah disbanding rata-rata kabupaten lainnya di Jawa Barat. Hasil survey BPTP Jawa Barat pada tahun 2016 kepada penyuluh pertanian menyatakan bahwa penerapan inovasi teknologi tanam jajar legowo 2:1 di Kabupaten Purwakarta termasuk paling rendah dibandingkan dengan kabupaten lain di Jawa Barat yaitu sebesar $29,8 \%$ dari total luas lahan sawah di Kabupaten Purwakarta. Rendahnya produktivitas padi di Kabupaten Purwakarta menunjukkan bahwa petani belum sepenuhnya mengadopsi inovasi teknologi yang mampu meningkatkan produktivitas tanaman padi (tanam jajar legowo 2:1).

Inovasi tanam jajar legowo 2:1 agar dapat diadopsi oleh petani akan melalui beberapa tahapan (proses adopsi) sebelum petani memutuskan menerima atau menolak suatu inovasi. Tahapan dalam proses adopsi inovasi dimulai dari tahap pengenalan, dimana seseorang mulai mengetahui tentang adanya inovasi. Kemudian dilanjutkan dengan tahap persuasi, dimana seseorang membentuk sikap terhadap inovasi. Selanjutnya tahap keputusan untuk menerima atau menolak inovasi. Akhirnya, berlanjut pada tahap 
konfirmasi, dimana seseorang mencari penguat bagi keputusan inovasi yang telah dibuat untuk terus melanjutkan penerapan inovasi atau pada akhirnya tidak menerapkan (Rogers, 1987).

Tingkat adopsi pada umumnya diukur dengan memerlukan selang waktu tertentu individu mempunyai tingkat penerapan yang lebih cepat dalam pengambilan keputusan yang dilakukan untuk mengadopsi suatu inovasi. Hal ini selaras dengan pendapat Rogers (1987) yang menyatakan bahwa tingkat adopsi pada umumnya diukur dengan memerlukan selang waktu tertentu untuk mengadopsi suatu inovasi. Oleh karena itu, kita dapat mengetahui tingkat adopsi dari tiap inovasi atau sistem, lebih daripada seseorang individu sebagai unit analisis. Inovasi yang dirasakan individu sebagai pemilik terbesar, kesesuaian dan lain-lain, lebih memiliki tingkat penerapan yang lebih cepat

Berdasarkan uraian d iatas, tujuan penelitian ini adalah untuk mengetahui tingkat adopsi inovasi tanam jajar legowo 2:1 di Kabupaten Purwakarta.

\section{METODE PENELITIAN}

Penelitian dilakukan dengan metode survey dengan teknik pengambilan sampel acak berimbang.
Populasi dalam penelitian ini adalah petani padi sawah yang telah dan masih menerapkan inovasi tanam jajar legowo 2:1 pasca program-program pemerintah (Demplot tanam jajar legowo 2:1, SLPTT, dan GP-PTT), di 3 kecamatan yang mewakili 3 kategori penerapan inovasi tanam jajar legowo 2:1 di Kabupaten Purwakarta berdasarkan kesamaan lokasi, agroekosistem, dan kesamaan penerima program-program pemerintah, yaitu Kecamatan Jatiluhur (rendah), Bojong (sedang), dan Pasawahan (tinggi). Berdasarkan informasi yang diperoleh dari Dinas Pangan dan Pertanian Kabupaten Purwakarta, petani peserta program GP-PTT (2017) yang telah menerima inovasi tanam jajar legowo 2:1 sebanyak 192 orang dengan rincian pada Tabel 1.

Tabel 1. Jumlah Populasi Penelitian

\begin{tabular}{|c|c|c|}
\hline No & Kecamatan & Jumlah petani (Orang) \\
\hline 1. & Jatiluhur & 54 \\
\hline 2. & Bojong & 55 \\
\hline 3. & Pasawahan & 83 \\
\hline \multicolumn{2}{|r|}{ Jumlah } & 192 \\
\hline Sum & $\begin{array}{l}\text { Dinas } \mathrm{F} \\
\text { Purwaka }\end{array}$ & $\begin{array}{l}\text { gan dan Pertanian Kab } \\
2018\end{array}$ \\
\hline
\end{tabular}
(Amirin dan Tatang, 2001) sebagai berikut:

$$
\begin{aligned}
n=\frac{\mathrm{N}}{1+N \cdot e^{2}} & =\frac{192}{1+192 \cdot(0,05)^{2}} \\
& =\frac{192}{1,48}=129,95=130
\end{aligned}
$$


Dimana:

$\mathrm{N}=$ Jumlah Populasi

$\mathrm{n}=$ Jumlah sampel

$\mathrm{e}=$ Batas toleransi kesalahan (error tolerance 5\%)

Berdasarkan perhitungan di atas, jumlah sampel dalam penelitian ini adalah sebanyak 130 orang. Teknik pengambilan sampel dilakukan secara

Tabel 2. Sampel Penelitian

\begin{tabular}{clccc}
\hline No & Kecamatan & Jumlah petani & Perhitungan sampel & Besar sampel \\
\hline 1. & Jatiluhur & 54 & $54 / 192 \times 130=36,6$ & 37 \\
2. & Bojong & 55 & $55 / 192 \times 130=37,2$ & 37 \\
3. & Pasawahan & 83 & $83 / 192 \times 130=56,2$ & 56 \\
\hline & Jumlah & $\mathbf{1 9 2}$ & & $\mathbf{1 3 0}$
\end{tabular}

Analisis deskriptif digunakan untuk mengetahui tingkat adopsi inovasi tanam jajar legowo 2:1. Skor tingkat adopsi inovasi tanam jajar legowo 2:1 diperoleh melalui beberapa pernyataan yang diberi nilai dari skala likert dengan 5 tingkatan berdasarkan tahapan dalam proses keputusan inovasi menurut rogers ( sangat setuju $=5$, setuju $=4$, ragu-ragu $=$ 3 , tidak setuju $=2$, dan sangat tidak setuju $=1)$. Tingkat adopsi inovasi tanam jajar legowo 2:1 dibedakan dalam 5 kategori adopsi, yaitu adopsi sangat rendah apabila hasil penghitungan berada dalam kisaran 0-20 persen, adopsi rendah apabila hasil penghitungan berada dalam kisaran 21-40 persen, adopsi sedang apabila hasil penghitungan berada dalam kisaran 41-60 persen, adopsi tinggi apabila hasil penghitungan berada dalam sampel acak berimbang (proportional random sampling). Teknik tersebut dilakukan untuk menyempurnakan penggunaan sampel kecamatan, sebab banyaknya subjek yang terdapat pada setiap kecamatan tidak sama sehingga sampel yang diteliti adalah seperti Tabel 2.

kisaran 61-80 persen, serta adopsi sangat tinggi apabila hasil penghitungan berada dalam kisaran 81-100 persen. Kriteria interpretasi skor menjadi 5 kategori tersebut mengacu pada Riduwan dan Sunarto (2012). Responden dianggap menerima inovasi dengan baik ketika tingkat adopsinya masuk dalam kategori sangat tinggi dan tinggi, sementara responden dengan tingkat adopsi sedang, rendah, dan sangat rendah dianggap kurang menerima inovasi dengan baik.

\section{HASIL DAN PEMBAHASAN}

\section{Karakteristik Responden}

\section{Umur Responden}

Umur seseorang dapat mempengaruhi kemampuan fisik dalam melakukan kegiatan usahataninya dan kemudian akan mempengaruhi adopsi 
teknologi. Umur seseorang bertambah dan kemampuan untuk bekerja secara fisik meningkat. Namun, pada batas umur tertentu, maka kemampuan fisik akan cenderung menurun dan produktivitas bekerja juga semakin menurun. Berdasarkan Tabel 3, mayoritas petani padi di Kabupaten Purwakarta berada pada kisaran 51-57 tahun. Menurut Mantra (2004), kisaran usia produktif manusia berkisar antara 15-64, dengan berpatokan pada pendapat Mantra tersebut maka petani padi di Kabupaten Purwakarta termasuk dalam petani tua produktif.

Tabel 3. Karakteristik Responden Bedasarkan Umur

\begin{tabular}{|c|c|c|c|c|c|c|c|c|}
\hline \multirow{2}{*}{ Umur Respoden } & \multicolumn{2}{|c|}{$\begin{array}{c}\text { Kec. } \\
\text { Jatiluhur }\end{array}$} & \multicolumn{2}{|c|}{$\begin{array}{c}\text { Kec. } \\
\text { Bojong }\end{array}$} & \multicolumn{2}{|c|}{$\begin{array}{c}\text { Kec. } \\
\text { Pasawahan }\end{array}$} & \multicolumn{2}{|c|}{ Total } \\
\hline & $\mathbf{f}$ & $\%$ & f & $\%$ & f & $\%$ & $\mathbf{f}$ & $\%$ \\
\hline 1. Usia lanjut ( $>64,75$ th) & 13 & 35,14 & 7 & 18,92 & 8 & 14,29 & 28 & 21,54 \\
\hline 2. Usia tua $(>57,92-\leq 64,75$ th $)$ & 8 & 21,62 & 10 & 27,03 & 18 & 32,14 & 36 & 27,69 \\
\hline 3. Usia sedang $(>51,08-\leq 57,92$ th) & 7 & 18,92 & 8 & 21,62 & 23 & 41,07 & 38 & 29,23 \\
\hline 4. Usia muda $(>44,25-\leq 51,08$ th $)$ & 9 & 24,32 & 11 & 29,73 & 7 & 12,50 & 27 & 20,77 \\
\hline 5. Usia sangat muda ( $\leq 44,25$ th) & 0 & 0,00 & 1 & 2,70 & 0 & 0,00 & 1 & 0,77 \\
\hline Jumlah & 37 & 100 & 37 & 100 & 56 & 100 & 130 & 100,00 \\
\hline
\end{tabular}

Petani padi kurang atau sama dengan 44 tahun memiliki persentase paling rendah diantara kategori umur lainnya, padahal umur tersebut produktif merupakan usia ideal untuk bekerja dan mempunyai kemampuan untuk meningkatkan produktivitas usahataninya serta memiliki kemampuan yang besar dalam menyerap informasi dan teknologi yang inovatif di bidang pertanian seperti inovasi tanam jajar legowo 2:1. Usia produktif tersebut merupakan usia ideal untuk bekerja dengan baik dan masih kuat untuk melakukan kegiatan-kegiatan di dalam usahatani dan di luar usahatani.

\section{Pendidikan Responden}

Pendidikan formal merupakan sarana belajar untuk meningkatkan pengetahuan (cognitive), sikap (attitude) dan keterampilan (psychomotor) seseorang. Pendidikan mempengaruhi tingkat berpikir dan penalaran dalam pengambilan keputusan maupun dalam bertindak. Fungsi pendidikan menurut Tilaar (1998) adalah menguak potensi individu dan cara manusia mampu mengontrol potensinya yang telah dikembangkan agar dapat bermanfaat bagi peningkatan kualitas hidupnya. Semakin tinggi pendidikan seseorang maka akan mempengaruhi cara berpikir, 
sikap dan perilakunya ke arah yang lebih rasional dalam menerima atau memahami inovasi teknologi yang diperolehnya.
Berdasarkan Tabel 4, mayoritas petani di Kabupaten Purwakarta bependidikan tidak tamat SD (Sekolah Dasar).

Tabel 4. Karakteristik Responden Berdasarkan Tingkat Pendidikan

\begin{tabular}{lcccccccc}
\hline \multirow{2}{*}{ Pendidikan Responden } & \multicolumn{2}{c}{$\begin{array}{c}\text { Kec. } \\
\text { Jatiluhur }\end{array}$} & \multicolumn{2}{c}{$\begin{array}{c}\text { Kec. } \\
\text { Bojong }\end{array}$} & \multicolumn{2}{c}{$\begin{array}{c}\text { Kec. } \\
\text { Pasawahan }\end{array}$} & \multicolumn{2}{c}{ Total } \\
\cline { 2 - 10 } & $\mathbf{f}$ & $\mathbf{\%}$ & $\mathbf{f}$ & $\mathbf{\%}$ & $\mathbf{f}$ & $\mathbf{\%}$ & f & \% \\
\hline 1. Sangat rendah $<6$ 6 th (tidak tamat & 12 & 32,43 & 16 & 43,24 & 20 & 35,71 & 48 & 36,92 \\
SD/SR) & 13 & 35,14 & 12 & 32,43 & 13 & 23,21 & 38 & 29,23 \\
2. Rendah 6 th (SD/SR) & 12 & 32,43 & 9 & 24,32 & 23 & 41,07 & 44 & 33,85 \\
3. Sedang 7-9 th (SMP) & 0 & 0,00 & 0 & 0,00 & 0 & 0,00 & 0 & 0,00 \\
4. Tinggi 10-12 th (SMA) & 0 & 0,00 & 0 & 0,00 & 0 & 0,00 & 0 & 0,00 \\
5. Sangat tinggi $\geq$ 13th (PT) & $\mathbf{3 7}$ & $\mathbf{1 0 0}$ & $\mathbf{3 7}$ & $\mathbf{1 0 0}$ & $\mathbf{5 6}$ & $\mathbf{1 0 0}$ & $\mathbf{1 3 0}$ & $\mathbf{1 0 0 , 0 0}$ \\
\hline Jumlah & & & & & & & \\
\hline
\end{tabular}

Berdasarkan hasil wawancara dengan fasilitator di lokasi penelitian, untuk menyampaikan inovasi tanam jajar legowo 2:1 hingga diterapkan oleh petani, memerlukan waktu yang cukup lama (minimal satu musim tanam), karena sebagian besar petani ingin selalu melihat hasilnya terlebih dahulu. Mereka tidak serta merta langsung menerapkan inovasi. Tingkat pendidikan formal petani diduga mempengaruhi pertimbangan rasional petani dalam menerima informasi maupun pengambilan keputusan inovasi. Hal ini sejalan dengan Rogers dan Shoemaker (1987) bahwa mereka yang berpendidikan tinggi adalah relatif lebih cepat dalam melaksanakan adopsi; begitu pula sebaliknya mereka yang berpendidikan rendah makin lambat mengadopsi.

\section{Tanggungan Keluarga Responden}

Jumlah anggota keluarga yang dimaksud dalam penelitian adalah seluruh anggota yang terdapat dalam rumah tangga, diukur dari jumlah orang yang berada dalam satu rumahtangga (saat wawancara. Jumlah anggota keluarga akan terkait dengan ketersediaan tenaga kerja keluarga. Tenaga kerja dalam keluarga merupakan asset modal tenaga kerja usahatani, yang juga sekaligus menjadi beban tanggung jawab bagi kepala keluarga (tanggungan keluarga) dalam pemenuhan kebutuhan hidupnya. Rumah tangga biasanya terdiri atas suami, istri, anak, orang tua, famili suami atau istri dan juga orang lain yang menjadi tanggungan kepala rumah tangga. Tabel 5 menunjukkan bahwa mayoritas petani padi di Kabupaten Purwakarta merupakan petani dengan 
jumlah tanggungan keluarga sedang (3 orang). Menurut BKKBN 2008 jumlah tanggungan keluarga tersebut termasuk dalam keluarga besar (>2 orang).

Tabel 5. Karakteristik Petani Berdasarkan Jumlah Tanggungan Keluarga

\begin{tabular}{|c|c|c|c|c|c|c|c|c|}
\hline \multirow{2}{*}{ Tanggungan Keluarga Responden } & \multicolumn{2}{|c|}{$\begin{array}{c}\text { Kec. } \\
\text { Jatiluhur }\end{array}$} & \multicolumn{2}{|c|}{$\begin{array}{c}\text { Kec. } \\
\text { Bojong }\end{array}$} & \multicolumn{2}{|c|}{$\begin{array}{c}\text { Kec. } \\
\text { Pasawahan } \\
\end{array}$} & \multicolumn{2}{|c|}{ Total } \\
\hline & f & $\%$ & f & $\%$ & f & $\%$ & f & $\%$ \\
\hline 1. Sangat tinggi ( $>4$ orang) & 2 & 5,41 & 4 & 10,81 & 6 & 10,71 & 12 & 9,23 \\
\hline 2. Tinggi (4) & 5 & 13,51 & 8 & 21,62 & 11 & 19,64 & 24 & 18,46 \\
\hline 3. Sedang (3) & 14 & 37,84 & 17 & 45,95 & 26 & 46,43 & 57 & 43,85 \\
\hline 4. Rendah ( 2 orang) & 6 & 16,22 & 6 & 16,22 & 11 & 19,64 & 23 & 17,69 \\
\hline 5. Sangat rendah $(<2$ orang $)$ & 10 & 27,03 & 2 & 5,41 & 2 & 3,57 & 14 & 10,77 \\
\hline Jumlah & 37 & 100 & 37 & 100 & 56 & 100 & 130 & 100,00 \\
\hline
\end{tabular}

Jumlah anggota keluarga sangat menentukan jumlah kebutuhan keluarga. Semakin banyak anggota keluarga berarti semakin banyak pula jumlah kebutuhan keluarga yang harus dipenuhi. Begitu pula sebaliknya, semakin sedikit anggota keluarga berarti semakin sedikit pula kebutuhan yang harus dipenuhi keluarga. Sehingga dalam keluarga yang jumlah anggotanya banyak, akan diikuti oleh banyaknya kebutuhan yang harus dipenuhi. Semakin besar ukuran rumahtangga berarti semakin banyak anggota rumahtangga yang pada akhirnya akan semakin berat beban rumah tangga untuk memenuhi kebutuhan sehariharinya.

\section{Intensitas Penyuluhan}

Intensitas penyuluhan merupakan frekuensi petani mendapatkan informasi yang dibutuhkannya. Intensitas penyuluhan sangat berperan dalam peningkatan pengetahuan petani. Oleh karena itu, peran petani secara partisipatif dan penyuluh haruslah bersinergi dengan baik, sehingga dampak dari penyuluhan itu sendiri dapat terlihat secara maksimal. Tabel 6 menunjukkan bahwa mayoritas petani mendapatkan penyuluhan pertanian dengan intensitas sedang. Berdasarkan wawancara dengan petani, alasan mereka tidak selalu hadir dalam kegiatan penyuluhan adalah karena sibuk bekerja dan alasan keluarga lainnya (mengantar anak dan istri, ada kepentingan yang tidak bisa ditinggalkan). Pertemuan rutin kelompok tani di Kabupaten Purwakarta umumnya dilakukan 6-12 kali dalam satu tahun. Dalam pertemuan rutin kelompok tani tersebut selain membahas permasalahan dalam kelompok tani juga dilakukan 
penyuluhan oleh penyuluh pertanian lapangan (PPL) untuk menyampaikan informasi inovasi pertanian yang dibutuhkan petani. Intensitas penyuluhan sangat penting dalam proses adopsi teknologi. Semakin tinggi mengikuti frekuensi penyuluhan, maka keberhasilan penyuluhan pertanian yang disampaikan semakin tinggi pula. Frekuensi petani dalam mengikuti penyuluhan yang meningkat disebabkan karena penyampaian yang menarik dan tidak membosankan serta yang disampaikan benar-benar bermanfaat bagi petani untuk usaha taninya (Sumbayak, 2006).

Tabel 6, Karakteristik Responden Berdasarkan Intensitas Penyuluhan Yang Diterima

\begin{tabular}{lllllllll}
\hline & \multicolumn{2}{c}{$\begin{array}{c}\text { Kec. } \\
\text { Jntensitas Penyuluhan }\end{array}$} & \multicolumn{2}{c}{$\begin{array}{c}\text { Kec. } \\
\text { Bojiluhur }\end{array}$} & \multicolumn{2}{c}{$\begin{array}{c}\text { Kec. } \\
\text { Pasawahan }\end{array}$} & \multicolumn{2}{c}{ Total } \\
\cline { 2 - 10 } & $\mathbf{f}$ & $\mathbf{\%}$ & $\mathbf{f}$ & $\mathbf{\%}$ & $\mathbf{f}$ & $\mathbf{\%}$ & f & \% \\
\hline 1. Sangat rendah $(\leq 3,5$ kali) & 2 & 5,41 & 4 & 10,81 & 4 & 7,14 & 10 & 7,69 \\
2. Rendah $(>3,5-\leq 4,5$ kali) & 15 & 40,54 & 8 & 21,62 & 12 & 21,43 & 35 & 26,92 \\
3. Sedang $(>4,5-\leq 5,5$ kali) & 11 & 29,73 & 13 & 35,14 & 18 & 32,14 & 42 & 32,31 \\
4. Tinggi $(>5,5-\leq 6,5$ kali) & 6 & 16,22 & 8 & 21,62 & 12 & 21,43 & 26 & 20,00 \\
5. Sangat tinggi $(>6,5$ kali) & 3 & 8,11 & 4 & 10,81 & 10 & 17,86 & 17 & 13,08 \\
\hline Jumlah & $\mathbf{3 7}$ & $\mathbf{1 0 0}$ & $\mathbf{3 7}$ & $\mathbf{1 0 0}$ & $\mathbf{5 6}$ & $\mathbf{1 0 0}$ & $\mathbf{1 3 0}$ & $\mathbf{1 0 0 , 0 0}$ \\
\hline
\end{tabular}

\section{Luas Lahan}

Lahan merupakan tempat berlangsungnya proses produksi. Semakin besar lahan yang digunakan maka semakin banyak input yang dibutuhkan oleh petani untuk berusahatani. Berdasarkan Tabel 7, mayoritas petani di Kabupaten Purwakarta mempunyai kepemilikan lahan sangat sempit, dengan luas kepemilikan $<0,25$ ha. Namun demikian, berdasarkan wawancara dengan responden, sebagian besar sepakat bahwa luas lahan sawah tidak menyurutkan niat mereka untuk mengadopsi inovasi tanam jajar legowo 2:1. Mereka mengatakan bahwa penerapan inovasi akan menyesuaikan dengan kepemilikan lahan yang mereka miliki. Hal ini berbeda dengan Birowo et al dalam Adjid (2001) yang menyatakan bahwa petani memiliki lahan yang luas sangat respon terhadap penerapan teknologi baru di sektor pertanian, sebaliknya pada lahan yang sempit para petani menganggapnya tidak efektif. 
Tabel 7. Karakteristik Responden Berdasarkan Luas Lahan

\begin{tabular}{|c|c|c|c|c|c|c|c|c|}
\hline \multirow[t]{2}{*}{ Luas Lahan } & \multicolumn{2}{|c|}{$\begin{array}{c}\text { Kec. } \\
\text { Jatiluhur }\end{array}$} & \multicolumn{2}{|c|}{$\begin{array}{c}\text { Kec. } \\
\text { Bojong }\end{array}$} & \multicolumn{2}{|c|}{$\begin{array}{c}\text { Kec. } \\
\text { Pasawahan }\end{array}$} & \multicolumn{2}{|c|}{ Total } \\
\hline & f & $\%$ & f & $\%$ & $\mathbf{f}$ & $\%$ & f & $\%$ \\
\hline 1. Sangat sempit $(\leq 0,25 \mathrm{ha})$ & 13 & 35,14 & 15 & 40,54 & 24 & 42,86 & 52 & 40,00 \\
\hline 2. Sempit $(0,25-0,49$ ha $)$ & 17 & 45,95 & 13 & 35,14 & 20 & 35,71 & 50 & 38,46 \\
\hline 3. Sedang $(0,50-0,99$ ha $)$ & 5 & 13,51 & 9 & 24,32 & 11 & 19,64 & 25 & 19,23 \\
\hline 4. Luas (>1 ha) & 2 & 5,41 & 0 & 0,00 & 1 & 1,79 & 3 & 2,31 \\
\hline Jumlah & 37 & 100 & 37 & 100 & 56 & 100 & 130 & 100,00 \\
\hline
\end{tabular}

\section{Pendapatan Keluarga}

Pendapatan keluarga petani dalam penelitian ini dibagi dalam 3 kategori, yaitu pendapatan rendah, sedang dan tinggi. Dapat dilihat pada Gambar 1.

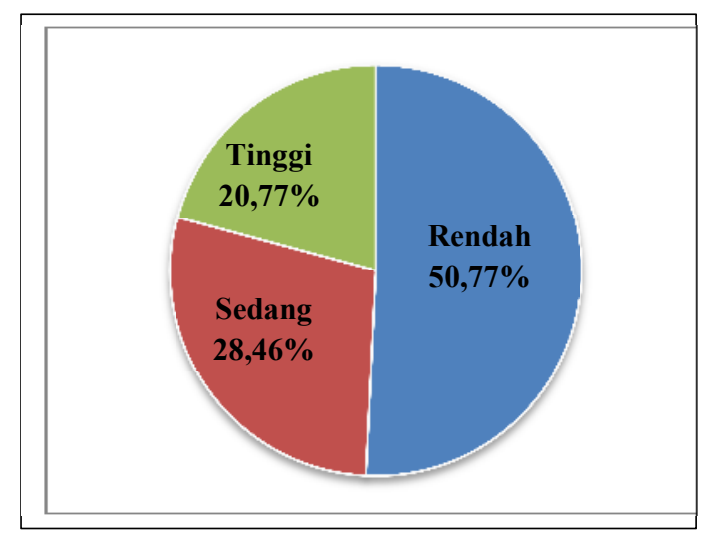

\section{Gambar 1. Karakteristik Responden Berdasarkan Pendapatan Keluarga}

Pendapatan petani merupakan nilai dari seluruh barang dan jasa yang dihasilkan oleh petani dalam suatu periode tertentu. Penghasilan petani yang diperoleh dari pendapatan bersih dari hasil pertanian ditambah dengan pendapatan-pendapatan dari sumber lain, yang terdiri atas penghasilan dari buruh tani, penghasilan dari pekerjaan/usaha lain, serta penghasilan dari anggota keluarga lain (di luar kepala keluarga). Mayoritas petani padi di Kabupaten Purwakarta mempunyai pendapatan keluarga rendah yaitu di bawah standar UMR Kabupaten Purwakarta (Rp 3.445.616,90). Pendapatan keluarga tersebut diperoleh dari usaha pertanian (budidaya dan kegiatan berburuh), serta diperoleh dari usaha non pertanian (buruh bangunan, ojek, berdagang). Pendapatan usahatani sering kali dikaitkan dengan pendapatan non usahatani, karena di selasela kegiatan usahatani para petani sering kali mengalihkan sisa waktunya melakukaan kegiatan di luar usahatani untuk menambah pendapatan petani atau yang disebut pendapatan keluarga, dan hasil dari pendapatan usahatani yang ditambah dengan pendapatan dari luar pertanian yaitu off farm (Suratiyah, 2008). 
Tingkat Adopsi Inovasi Tanam Jajar Legowo 2:1

Tingkat adopsi adalah kecepatan relatif dimana inovasi diadopsi oleh anggota sistem sosial. Umumnya diukur sebagai jumlah individu yang mengadopsi ide baru dalam periode tertentu, seperti setiap tahun. Jadi tingkat adopsi adalah indikator numerik dari kecuraman kurva adopsi untuk suatu inovasi (Emerson, 1995 dalam Rogers, 2003).

Inovasi tanam jajar legowo 2:1 yang diintroduksikan berdasarkan persentase tahapan penerapan inovasi tanam jajar legowo 2:1 di lokasi penelitian dapat dilihat pada Gambar 2.

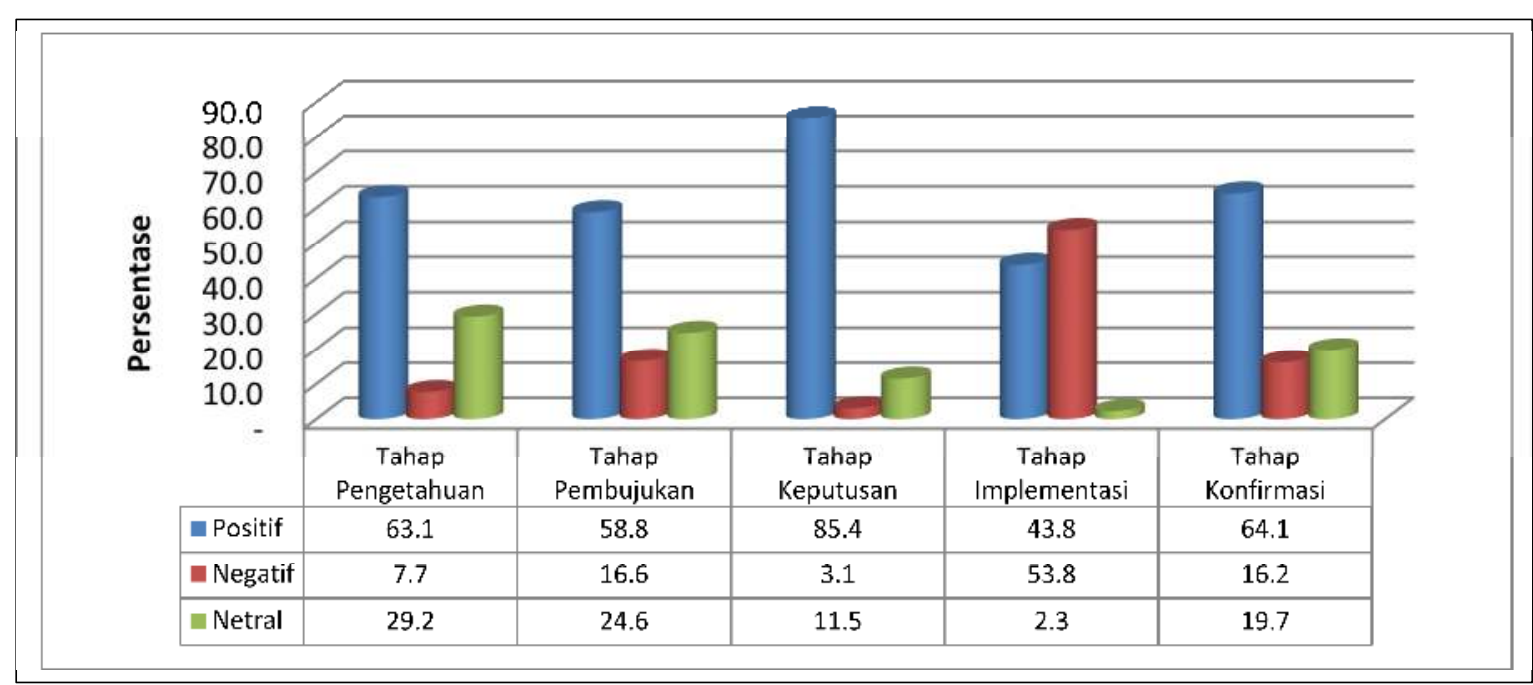

Gambar 2. Persentase Tingkat Adopsi Inovasi Tanam Jajar Legowo 2:1 di Lokasi Penelitian

Proporsi tahapan penerapan inovasi tanam jajar legowo 2:1 di lokasi penelitian berupa pernyataan tersebut diperoleh dari wawancara langsung dengan petani yang telah melaksanakan inovasi. Selain itu, informasi diperoleh melalui observasi langsung dan menghimpun persepsi petani terhadap inovasi tanam jajar legowo 2:1 yang telah diujicobakan. Hasil pernyataan petani pada tahapan adopsi di lokasi penelitian disajikan pada Tabel 8. 
Tabel 8. Kondisi Petani di Pada Berbagai Tahapan Adopsi Di Lokasi Penelitian

\begin{tabular}{|c|c|c|c|c|}
\hline No. & Tahapan Adopsi & $\begin{array}{c}\text { Kondisi } \\
\text { positif }(\%)\end{array}$ & $\begin{array}{c}\text { Kondisi } \\
\text { Negatif (\%) }\end{array}$ & $\begin{array}{c}\text { Netral } \\
(\%)\end{array}$ \\
\hline \multirow[t]{3}{*}{1.} & Pengetahuan & & & \\
\hline & Prinsip dasar inovasi tanam jajar legowo $2: 1$ & 63,1 & 7,7 & 29,2 \\
\hline & Rata-rata & 63,1 & 7,7 & 29,2 \\
\hline \multirow[t]{7}{*}{2.} & Pembujukan & & & \\
\hline & - Kesukaan terhadap inovasi tanam jajar legowo 2:1 & 65,4 & 2,3 & 32,3 \\
\hline & $\begin{array}{l}\text { - Mendiskusikan inovasi tanam jajar legowo 2:1 dengan } \\
\text { petani lain }\end{array}$ & 23,1 & 67,7 & 9,2 \\
\hline & - Kesesuaian dengan keinginan & 53,1 & 6,9 & 40,0 \\
\hline & - Keunggulan inovasi tanam jajar legowo 2:1 & 67,7 & 2,3 & 30,0 \\
\hline & - Dukungan terhadap inovasi tanam jajar legowo 2:1 & 84,6 & 3,8 & 11,5 \\
\hline & Rata-rata & $\mathbf{5 8 , 8}$ & 16,6 & 24,6 \\
\hline \multirow[t]{6}{*}{3.} & Pengambilan Keputusan & & & \\
\hline & - Minat mencari informasi lebih lanjut & 80,0 & 2,3 & 17,7 \\
\hline & - Minat mencoba menerapkan & 89,2 & 2,3 & 8,5 \\
\hline & - Mempertimbangkan terlebih dahulu & 90,8 & 4,6 & 4,6 \\
\hline & - Keputusan sendiri & 81,5 & 3,1 & 15,4 \\
\hline & Rata-rata & 85,4 & 3,1 & $\mathbf{1 1 , 5}$ \\
\hline \multirow[t]{5}{*}{4.} & Implementasi & & & \\
\hline & - Mencoba dalam skala kecil & 44,6 & 50,8 & 4,6 \\
\hline & $\begin{array}{l}\text { - Penerapan tanam jajar legowo } 2: 1 \text {, karena ada bantuan } \\
\text { pemerintah }\end{array}$ & - & 100,0 & 0,0 \\
\hline & - Akan menerapkan tanam jajar legowo 2:1 lebih lanjut? & 86,9 & 10,8 & 2,3 \\
\hline & Rata-rata & 43,8 & $\mathbf{5 3 , 8}$ & 2,3 \\
\hline \multirow[t]{5}{*}{5.} & Konfirmasi & & & \\
\hline & - Inovasi tanam jajar legowo 2:1 layak diterapkan & 86,2 & - & 13,8 \\
\hline & - Yakin akan terus menerapkan/mengadopsi & 70,0 & 2,3 & 27,7 \\
\hline & - Mempromosikan jarwo & 36,2 & 46,2 & 17,7 \\
\hline & Rata-rata & 64,1 & 16,2 & 19,7 \\
\hline
\end{tabular}

\section{Tahap Pengetahuan (knowledge} stage)

Berdasarkan hasil wawancara dan informasi lapangan menunjukkan bahwa seluruh responden telah mendapatkan informasi atau pengetahuan tentang inovasi tanam jajar legowo 2:1. Hasil terhadap tingkat pengetahuan responden dengan beberapa pertanyaan dan pernyataan terkait : a) Perolehan informasi tentang inovasi tanam jajar legowo 2:1, b) Pemahaman pesan-pesan informasi tanam jajar legowo 2:1 dan c) Pengetahuan atau keterampilan untuk adopsi inovasi, maka dilihat pada Tabel 6, sebesar $63,1 \%$ responden sudah mengetahui dengan benar manfaat dan kelebihan dari inovasi tanam jajar legowo $2: 1$. Sebanyak $7,7 \%$ responden masih minim pengetahuan tentang inovasi tanam jajar legowo 2:1, responden belum mengetahui dengan benar manfaat dan kelebihan dari pelaksanaannya tanam jajar legowo 2:1. 
Hal ini ditunjukkan dari jawaban responden yang mengatakan bahwa dengan tanam jajar legowo 2:1 lahan banyak terbuang, dengan tanam jajar legowo 2:1 perkembangan hama khususnya keong mas meningkat, padahal tidak ada hubungan antara pola tanam jajar legowo 2:1 dengan perkembangan keong mas. Sebanyak $29,2 \%$ responden menjawab netral, responden yang menyatakan netral kemungkinan belum memahami inovasi tanam jajar legowo 2:1.

Berdasarkan kondisi tersebut diatas maka tingkat adopsi petani padi di Kabupaten Purwakarta terhadap inovasi tanam jajar legowo 2:1 pada tahap pengetahuan adalah sebesar 63,1\%, tingkat adopsi tersebut berada pada kategori tinggi, artinya petani menerima dengan baik inovasi tanam jajar legowo 2:1. Dengan melihat tingkat adopsi tersebut maka, informasi mengenai inovasi tanam jajar legowo 2:1 harus terus disampaikan melalui berbagai saluran komunikasi yang ada di lapangan, bisa melalui media elektronik, media cetak, maupun komunikasi interpersonal melalui PPL maupun antar sesama petani. Ada beberapa sumber yang menyebutkan tahap pengetahuan sebagai tahap "Awareness". Tahap ini merupakan tahap penyebaran informasi tentang inovasi baru, dan saluran yang paling efektif untuk digunakan adalah saluran media massa. Artinya, pemilihan media dalam tahap ini agar dapat dipilih media yang dapat menyentuh orang banyak. Dalam tahap ini kesadaran petani akan mencari atau membentuk pengertian inovasi dan tentang bagaimana inovasi tersebut dapat berfungsi. Rogers mengatakan ada tiga macam pengetahuan yang dicari masyarakat dalam tahapan ini, yakni: (a) kesadaran bahwa inovasi itu ada; (b) pengetahuan akan penggunaan inovasi tersebut; dan (c) pengetahuan yang mendasari bagaimana fungsi inovasi tersebut bekerja.

\section{Tahap pembujukan (persuasion stage)}

Tahap kedua ini terjadi lebih banyak dalam tingkat pemikiran petani. Petani mengukur keuntungan yang akan ia dapat jika mengadopsi inovasi tanam jajar legowo 2:1 secara personal. Berdasarkan evaluasi dan diskusi dengan orang lain, petani mulai cenderung untuk mengadopsi atau menolak inovasi tersebut. Pada Tabel 6, dapat dilihat bahwa hanya $23,1 \%$ petani responden pada tahap ini yang mendiskusikan tanam jajar legowo 2:1 dengan petani lainnya, sisanya $67.7 \%$ tidak mendiskusikan 
dengan petani lain. Dalam tahapan ini dapat dilihat petani membentuk sikap atau memiliki sifat yang menyetujui atau tidak menyetujui terhadap inovasi tanam jajar legowo 2:1. Dalam tahap persuasi ini, petani biasanya akan mencari tahu lebih dalam informasi tentang inovasi baru dan keuntungan menggunakan informasi tersebut. Yang membuat tahapan ini berbeda dengan tahapan pengetahuan adalah pada tahap pengetahuan yang berlangsung adalah proses memengaruhi kognitif, sedangkan pada tahap persuasi, aktifitas mental yang terjadi adalah mempengaruhi afektif. Pada tahapan ini petani akan lebih terlibat secara psikologis dengan inovasi. Kepribadian dan norma-norma sosial yang dimiliki petani akan menentukan bagaimana ia mencari informasi, bentuk pesan yang bagaimana yang akan ia terima dan yang tidak, dan bagaimana cara ia menafsirkan makna pesan yang ia terima berkenaan dengan informasi tersebut. Sehingga pada tahapan ini petani akan membentuk persepsi umumnya tentang inovasi tersebut. Secara umum $(84,6 \%)$ petani responden menyukai inovasi tanam jajar legowo 2:1 dan siap mendukung pengembangan tanam jajar legowo 2:1. 67,7\% menilai bahwa tanam jajar legowo 2:1 itu baik untuk dikembangkan dan 53,1\% telah sesuai dengan keinginan petani.

Berdasarkan Gambar 2, maka tingkat adopsi petani padi di Kabupaten Purwakarta terhadap inovasi tanam jajar legowo 2:1 pada tahap pembujukan adalah sebesar 58,8\%, tingkat adopsi tersebut berada pada kategori sedang, artinya petani kurang menerima dengan baik inovasi tanam jajar legowo 2:1. Beberapa ciri-ciri inovasi yang biasanya dicari pada tahapan ini adalah a) rasa suka terhadap inovasi, b) mendiskusikan dengan orang lain, c) menerima pesanpesan inovasi, d) membentuk gambaran positif tentang inovasi, dan e) mendukung perilaku inovatif..

\section{Tahap pengambilan keputusan (decision stage) \\ Pada tahap ini, petani membuat} keputusan akhir apakah mereka akan mengadopsi atau menolak sebuah inovasi. Namun bukan berarti setelah melakukan pengambilan keputusan ini lantas menutup kemungkinan terdapat perubahan dalam pengadopsian. Di tahapan ini petani terlibat dalam aktivitas yang membawa pada suatu pilihan untuk mengadopsi inovasi tanam jajar legowo 2:1 atau tidak sama sekali. Adopsi adalah keputusan untuk menggunakan 
sepenuhnya ide baru sebagai cara tindak yang paling baik.

Tabel 6 menunjukkan bahwa 81,5 $\%$ keputusan menerapkan atau tidaknya tanam jajar legowo 2:1 merupakan hasil keputusan individu, artinya penyadaran terhadap individu lebih penting sehingga perlu dilakukan pendekatan personal antara petugas dan petani calon adopter. Proses keputusan inovasi memiliki beberapa tipe yakni: (a) otoritas adalah keputusan yang dipaksakan kepada seseorang oleh individu yang berada dalam posisi atasan; (b) individual adalah keputusan dimana individu yang bersangkutan mengambil peranan dalam pembuatannya. Keputusan individual terbagi menjadi dua macam, yakni: pertama, keputusan opsional adalah keputusan yang dibuat oleh seseorang, terlepas dari keputusan yang dibuat oleh anggota sistem, dan dua keputusan kolektif adalah keputusan dibuat oleh individu melalui konsesnsus dari sebuah sistem sosial; (c) kontingen adalah keputusan untuk menerima atau menolak inovasi setelah ada keputusan yang mendahuluinya; dan (d) Konsekuensi adalah perubahan yang terjadi pada individu atau suatu sistem sosial sebagai akibat dari adopsi atau penolakan terhadap inovasi. Pada Tabel 6 dapat dilihat bahwa $89,2 \%$ petani responden berminat kembali menerapkan tanam jajar legowo 2:1, mereka berminat mencari informasi lebih lanjut (mendalam) pengetahuan tentang tanam jajar legowo 2:1. Ciri-ciri pada tahap ini adalah : a) minat untuk mencari informasi lebih lanjut tentang inovasi, b) minat untuk mencoba inovasi tersebut dan c) kembali mempertimbangkan teknologi.

Berdasarkan Gambar 2, maka tingkat adopsi petani padi di Kabupaten Purwakarta terhadap inovasi tanam jajar legowo 2:1 pada tahap pengambilan keputusan adalah sebesar 85,4\%, tingkat adopsi tersebut berada pada kategori sangat tinggi, artinya petani menerima dengan baik inovasi tanam jajar legowo 2:1. Menurut Rogers (2003), pada tahap ini petani yang mengadopsi terbagi menjadi dua yaitu petani yang akan melanjutkan adopsi dengan masuk ke tahapan implementasi, dan petani yang tidak melanjutkan yaitu hanya berada di tahap pengetahuan saja. Sedangkan pada petani yang menolak adopsi menurut Rogers terbagi menjadi dua, yaitu menolak dan mengadopsi kemudian.

4. Tahap implementasi (implementation stage)

Pada tahap ini petani mulai menggunakan inovasi tanam jajar legowo 
2:1 sambil mempelajari lebih jauh tentang inovasi tersebut. Tahapan ini hanya searah, jika pada tahap sebelumnya petani memilih untuk mengadopsi inovasi tanam jajar legowo 2:1 tersebut. Dalam tahap ini, petani akan menggunakan inovasi tanam jajar legowo 2:1 walau dalam skala kecil. Jika di tahapan sebelumnya proses yang terjadi kepada petani lebih kepada mental exercise yakni berpikir dan memutuskan, dalam tahap pelaksanaan ini proses yang terjadi lebih kearah perubahan tingkah laku sebagai bentuk dari penggunaan ide baru tersebut. Hal tersebut ditunjukkan dengan : a) menggunakan inovasi tanam jajar legowo 2:1 dalam skala kecil, dan b) penggunaan inovasi yang berlanjut. Pada tahap ini, petani responden pada musim sebelumnya hanya $44,6 \%$ yang baru mencoba pada skala kecil, sisanya sebesar 50,8\% mereka melihat terlebih dahulu performa dari tanam jajar legowo $2: 1$. Setelah melihat dan melalui proses tahapan adopsi, $86,9 \%$ petani akan mencoba cara tanam tanam jajar legowo $2: 1$.

Berdasarkan Gambar 2, tingkat adopsi petani padi di lokasi penelitian terhadap inovasi tanam jajar legowo 2:1 pada tahap implementasi adalah sebesar $43,8 \%$, tingkat adopsi tersebut berada pada kategori sedang, artinya petani kurang menerima dengan baik inovasi tanam jajar legowo 2:1. Beberapa alasan yang dikemukakan oleh petani pada tahap implementasi ini adalah: petani berkeinginan untuk menerapkan inovasi tanam jajar legowo 2:1, tetapi mereka belum mau mencobanya dalam skala kecil karena keterbatasan modal. Tetapi jika pemerintah memfasilitasi sarana produksi untuk ujicoba dalam skala kecil (demplot) di lahan mereka, petani bersedia untuk melaksanakannya.

\section{Tahap konfirmasi (confirmation stage) \\ Pada tahap ini, setelah sebuah} keputusan dibuat, petani kemudian akan mencari pembenaran atas keputusan mereka. Apakah inovasi tersebut diadopsi ataupun tidak, seseorang akan mengevaluasi akibat dari keputusan yang mereka buat. Tidak menutup kemungkinan petani kemudian mengubah keputusan yang tadinya menolak jadi menerima inovasi setelah melakukan evaluasi. Tahap konfirmasi (confirmation), tahap terakhir ini adalah tahapan dimana petani akan mengevaluasi dan memutuskan untuk terus menggunakan inovasi baru tersebut atau menyudahinya. Selain itu, petani akan mencari penguatan atas keputusan 
yang telah ia ambil sebelumnya. Apabila, petani tersebut menghentikan penggunaan inovasi hal tersebut dikarenakan oleh hal yang disebut disenchantment discontinuance dan atau replacement discontinuance. Disenchantment discontinuance disebabkan oleh ketidakpuasan petani terhadap inovasi tersebut sedangkan replacement discontinuance disebabkan oleh adanya inovasi lain yang lebih baik. Ciri responden pada tahap ini adalah a) pengakuan tentang keuntungan mengimplementasikan inovasi tanam jajar legowo 2:1, b) mengintegrasikan inovasi secara berkelanjutan dan c) mempromosikan inovasi tanam jajar legowo 2:1 kepada orang lain. Tabel 6 menunjukkan bahwa $86,2 \%$ petani setuju bahwa tanam jajar legowo 2:1 sangat layak diterapkan dilihat dari sisi ekonomi (menguntungkan) dan 70,0\% petani yakin bahwa akan terus mengembangkan tanam jajar legowo 2:1 pada musim-musim selanjutnya, dan $46 \%$ petani akan mempromosikan tanam jajar legowo 2:1 kepada petani lainnya.

Berdasarkan Gambar 2, tingkat adopsi petani terhadap inovasi tanam jajar legowo 2:1 pada tahap konfirmasi di lokasi penelitian adalah $64,1 \%$, tingkat adopsi tersebut berada pada kategori tinggi, artinya petani menerima dengan baik inovasi tanam jajar legowo 2:1. Angka tersebut tidak menutup kemungkinan akan berubah pada saat musim berikutnya, bisa naik dan bisa juga turun. Berdasarkan wawancara dengan petani, beberapa alasan yang memperkuat bahwa tingkat adopsi di lokasi penelitian tersebut masih akan berubah adalah sebagai berikut: (a) petani masih menggantungkan pada program dari pemerintah dalam pelaksanaan tanam jajar legowo 2:1, (b) petani kesulitan dalam menerapkannya karena keterbatasan tenaga jasa tanam legowo 2:1, walaupun ada jasa tanam yang bersedia tetapi mereka akan meminta bayaran lebih dari biasanya, jasa tanam beranggapan bahwa tanam jajar legowo 2:1 sulit dan menambah pekerjaan, (c) petani sudah mencoba menerapkan tetapi hasilnya tidak sesuai dengan perkiraan hasil yang tidak sesuai tersebut disebabkan karena kurang optimal dalam pemupukan dan pengendalian hama penyakit, (d) petani yang tidak menerapkan masih mempunyai keinginan untuk menerapkan tanam jajar legowo 2:1 pada musim berikutnya dengan alasan masih penasaran, karena melihat keberhasilan petani lainnya yang sudah menerapkan inovasi tanam jajar legowo 
$2: 1$, dan e) petani yang berstatus penggarap sudah ada keinginan untuk menerapkan inovasi tetapi pemilik lahan tidak menginginkannya.

Dalam tahap proses adopsi terkadang petani tidak menyadari saat kapan mereka telah melalui tahapan proses tersebut dan juga tidak semua tahapan-tahapan proses adopsi dilakukan secara berurutan. Petani yang menerapkan tanam jajar legowo 2:1 pada saat penelitian adalah petani yang sudah melalui proses tahapan adopsi. Petani yang belum menerapkan inovasi umumnya telah berkeinginan mengadopsi teknologi Jajar Legowo 2:1, tapi belum dapat melakukannya dalam waktu dekat karena berbagai alasan yang sudah dikemukan sebelumnya. Petani yang belum menerapkan tersebut belum mencapai tahap konfirmasi dan petani tersebut masih butuh waktu untuk mengadopsi inovasi tanam jajar legowo $2: 1$.

\section{KESIMPULAN DAN SARAN}

Tingkat adopsi petani terhadap inovasi tanam jajar legowo 2:1 di Kabupaten Purwakarta pada tahap pengetahuan adalah $63,1 \%$ (tinggi), tahap pembujukan $58.8 \%$ (sedang), tahap pengambilan keputusan $85,4 \%$ (sangat tinggi), tahap implementasi 43,8\% (sedang), dan tahap konfirmasi $64,1 \%$ (tinggi).

Dengan melihat tingkat adopsi tersebut maka peran PPL sangat dibutuhkan untuk terus mendampingi petani dan meyakinkan petani agar petani memiliki sifat positif terhadap inovasi tanam jajar legowo 2:1. Dibutuhkan dukungan secara terus menerus dari lembaga penyuluhan (BPP/BP3K) serta peran PPL untuk menyediakan informasi inovasi tanam jajar legowo 2:1 melalui media yang dikemas secara menarik sehingga petani tidak berhenti di tengah jalan yang pada akhirnya akan menolak inovasi. Dengan melihat kondisi tersebut maka peran pemerintah melalui programprogram mendukung penerapan inovasi tanam jajar legowo 2:1 masih dibutuhkan oleh petani.

\section{DAFTAR PUSTAKA}

Adjid, D.A. (2001). Penyuluhan Pertanian. Jakarta: Yayasan Sinar Tani.

Amirin, T.M. (2011). Populasi dan sampel penelitian 4: Ukuran sampel rumus Slovin. https://tatangmanguny.word press.com. Diakses 12 November 2018.

Badan Pusat Statistik Provinsi Jawa Barat. (2012). Provinsi Jawa Barat dalam Angka 2012. Bandung: Badan Pusat Statistik Provinsi Jawa Barat.

. (2013). Provinsi Jawa Barat dalam Angka 2013. Bandung: 
Badan Pusat Statistik Provinsi Jawa Barat. . (2014). Provinsi Jawa Barat dalam Angka 2014 Bandung: Badan Pusat Statistik Provinsi Jawa Barat.

. (2015). Provinsi Jawa Barat dalam Angka 2015. Bandung: Badan Pusat Statistik Provinsi Jawa Barat.

. (2016). Provinsi Jawa Barat dalam Angka 2016. Bandung: Badan Pusat Statistik Provinsi Jawa Barat.

- (2017). Provinsi Jawa Barat dalam Angka 2017. Bandung: Badan Pusat Statistik Provinsi Jawa Barat.

Bagoes, I.M. (2004). Filsafat Penelitian \& Metode Penlitian Sosial. Yogyakarta: Pustaka Belajar.

BPTP Jawa Barat. (2016). Laporan Tahunan Balai Pengkajian Teknologi Pertanian Jawa Barat. Badan Litbang Pertanian. Kementerian Pertanian Tahun 2016

Badan Pusat Statistik Kabupaten Purwakarta. (2018). Kabupaten Purwakarta Dalam Angka 2018. Purwakarta.

Dinas Pangan dan Pertanian Kabupaten Purwakarta. (2018). Basis Data 2018. Dinas Pangan dan Pertanian Kabupaten Purwakarta.

Sutrisna, N. dan Sunandar, N. (2012). Pemasyarakatan tanam padi Jajar Legowo 2:1 di Jawa Barat. http://jabar.litbang.pertanian.go.id/i ndex.php/info-teknologi/14alsin/203-legowo13.

Pemasyarakatan tanam padi Jajar Legowo 2:1 di Jawa Barat. Diakses 12 November 2018.
Tilaar, H.A.R. (1998). Manajemen Pendidikan Nasional; Kajian Pendidikan Masa Depan. Bandung: Remaja Rosdakarya.

Permadi, K., B. Sunandar, dan Nurnayetti. (2013). Peningkatan Produktivitas Padi melalui Inovasi Teknologi Spesifik Lokasi untuk Mencapai Swasembada Beras. Dalam Prosiding Seminar Nasional Akselerasi Pemanfaatan Teknologi Pertanian Spesifik Lokasi mendukung Ketahanan Pangan dan Kesejahteraan Petani Nelayan. Badan Penelitian dan Pengembangan Pertanian, pp. 140145.

Rogers EM. dan Shoemekers F. (1987). Comunication of Inovation. Terjemahan oleh Hanafi A. Memasyarakatkan Ide-ide Baru. Surabaya: Usana Offset Printing.

Rogers E.M. (2003). Diffusion of Innovations. Fifth Edition. The Free Press. A Division of Simon \& Schuster, Inc. 1230 Avenue of The Americas New York. NY 10020.

Suratiyah. (2008). Ilmu Usahatani. Jakarta: Penebar Swadaya.

Sumbayak, J. (2006). Materi, Metode dan Media Penyuluhan. Medan: Fakultas Pertanian, Universitas Sumatra Utara

Suriapermana, S., I. Nurhati dan Y.Surdianto. (1999). Teknologi Padi Dengan Cara Tanam Legowo Pada Lahan Sawah Irigasi. Makalah Disampaikan Pada Simposium Tanaman pangan IV. Bogor, 22-24 Nopember 1999. 